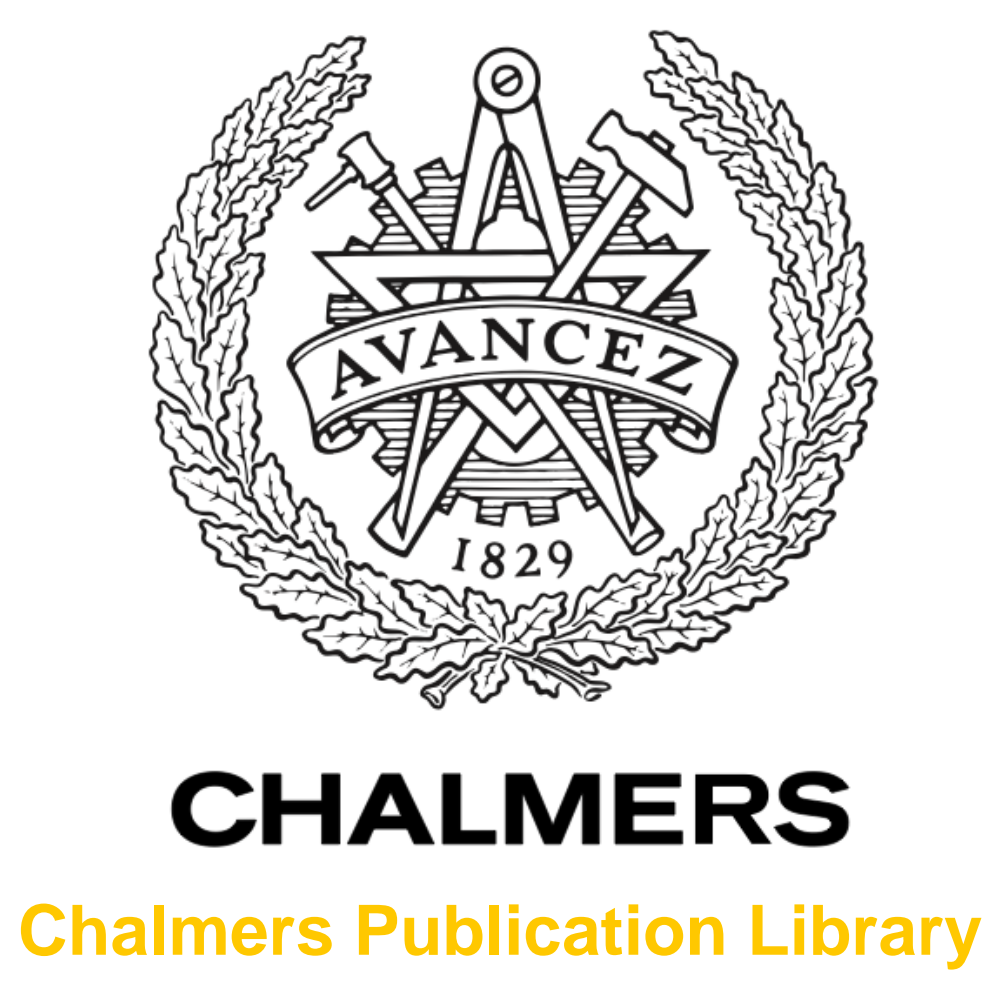

\author{
Building-Stock Aggregation through Archetype Buildings: France, Germany, Spain \\ and the UK
}

This document has been downloaded from Chalmers Publication Library (CPL). It is the author's version of a work that was accepted for publication in:

Building and Environment (ISSN: 0360-1323)

Citation for the published paper:

Mata, É. ; Sasic Kalagasidis, A. ; Johnsson, F. (2014) "Building-Stock Aggregation through Archetype Buildings: France, Germany, Spain and the UK". Building and Environment, vol. 81 pp. $270 \hat{2} 282$.

http://dx.doi.org/10.1016/j.buildenv.2014.06.013

Downloaded from: http://publications.lib.chalmers.se/publication/199226

Notice: Changes introduced as a result of publishing processes such as copy-editing and formatting may not be reflected in this document. For a definitive version of this work, please refer to the published source. Please note that access to the published version might require a subscription.

Chalmers Publication Library (CPL) offers the possibility of retrieving research publications produced at Chalmers University of Technology. It covers all types of publications: articles, dissertations, licentiate theses, masters theses, conference papers, reports etc. Since 2006 it is the official tool for Chalmers official publication statistics. To ensure that Chalmers research results are disseminated as widely as possible, an Open Access Policy has been adopted.

The CPL service is administrated and maintained by Chalmers Library. 


\title{
Building-Stock Aggregation through Archetype Buildings: France, Germany, Spain and the UK
}

\author{
Corresponding author \\ É. Mata \\ Division of Energy Technology \\ Department of Energy and Environment \\ Chalmers University of Technology, Gothenburg, Sweden \\ e-mail: mata@chalmers.se \\ Desk phone : $+46(0) 317725250$ \\ Fax : +46(o)31 7723592 \\ Postal address : \\ Hörsalsvägen $7 \mathrm{~b}, 4$ th floor \\ SE- 41296 Gothenburg, Sweden
}

Other authors
A. Sasic Kalagasidis,
Department of Civil and Environmental Engineering
Chalmers University of Technology, Gothenburg, Sweden
e-mail: angela.sasic@ chalmers.se,
F. Johnsson
Department of Energy Technology
Chalmers University of Technology, Gothenburg, Sweden
e-mail: filip.johnsson@chalmers.se

\begin{abstract}
(150 - 200 words)
Knowledge regarding the characteristics of national building stocks is fundamental to understanding how the energy performance of the building stock can be improved. To facilitate large diversity and a number of buildings for such analyses, this paper presents a methodology by which national building stocks may be aggregated through archetype buildings. The methodology has been implemented and verified in four EU countries in regions with different climates, namely France, Germany, Spain and the UK. These countries account for about half of the final energy consumption of the EU-28 buildings. The analysis includes the residential and non-residential sectors (residential sector only for Germany). The number of archetypes per country has been defined according to different categories of building type, construction year, climate region and the main fuel source for heating purposes. The accuracy of the description is validated by simulating energy demand using the ECCABS Building Stock Model, and comparing the final energy demand modelled with corresponding statistical data. The total final energy demand calculated for these countries differs from available statistics by between $-6 \%$ and $+2 \%$, which is considered satisfactory. The proposed description of the building stock is being used as a basis for analyzing the potential for and cost of energy conservation measures.
\end{abstract}

\section{KEYWORDS}

archetype buildings, EU building stock, energy demand, ECCABS Model, energy simulation 


\section{INTRODUCTION}

\subsection{Background}

Knowledge regarding the characteristics of building stocks is fundamental to understanding how the energy performance of the building stock can be improved [1][2]. What are the size and structure of the building stock in the European Union (EU)? Are there sufficiently robust data for the buildings in each member state (MS) upon which to base studies of the energy use of these building stocks? Kohler and Hassler [1] used the German building stock as a case study and concluded that most studies are strongly limited by the absence of reliable statistical data, and international research confirmed the global scale of this knowledge gap [3]. Similar conclusions have been reached by other analysts [4][5][6][7]. Nevertheless, despite the apparent paucity of consistent data, there has been a surge in recent years in the development and use of energy consumption models depicting national building stocks [8].

For the purpose of modelling its energy demand, a building stock can be described through representative buildings in terms of sample buildings or archetypes [2]. Sample buildings are designated as representing actual buildings (with data obtained from measurements) of the existing stock. As the building stock of a country consists of buildings with varying characteristics, an extensive sample of the buildings is required in order to derive an accurate picture of the thermal characteristics of the building stock. Therefore, establishment of such a sample would require significant efforts towards measuring and quantifying the parameters of a building sample. However, archetypal buildings are statistical composites of the features found within a category of buildings in the stock [3] derived from available data of the national building stock. Thus, despite the paucity of real building data, archetype buildings can be derived.

Although these descriptions do not include all relevant parameters for determining the energy demand, the literature provides descriptions of the building stock for several EU countries according to certain categories of samples and/or archetypes (cf. for France: [9][10]; for Germany: [11][12]; for Spain: [13][14]; and for the UK: [15][16][17][18][19]). For instance, only heated floor areas or the number of buildings are provided. On an EU level, there are examples of a more comprehensive description of a set of existing buildings [20], including the noteworthy effort to gather relevant data in the European TABULA Project [21], which has recently mapped data of existing residential buildings of 13 MSs. However, TABULA [21] has only very recently presented a quantification of the frequency in the building stock of the existing buildings described (no quantification is given in [20]). Therefore, despite such buildings constituting so-called typologies, they are not representative in a way that would allow an extrapolation of the description of the buildings to represent all residential and nonresidential buildings in each of the EU MSs investigated.

Besides different use and building traditions, a description of the building stock should reflect the climate zone where the building stock is located. The studies by Ciscar [22] and Tsikaloudaki [23] propose that the climates within EU could be represented by three or five zones, respectively, dependent on whether only heating [22] or both heating and cooling [23] degree days are calculated. To the authors' knowledge, no studies representative of the EU have described the building stocks of these zones climatically. Thus, there is much additional work to be done in order to arrive at a description of the characteristics of EU buildings on a level which may serve as a basis for modelling the effect of improvements in energy performance. Buildings in the EU are a particularly interesting object of study, not only because the EU has a concrete regulatory framework and a set of energy and environmental 
targets, but also because the building sector accounts for $35 \%-40 \%^{1}$ of the final total energy consumption (25\%-27\% residential, 10\%-13\% non-residential) in EU-28 and $25 \%-40 \%$ of the associated carbon dioxide $\left(\mathrm{CO}_{2}\right)$ emissions ${ }^{2}(15 \%-27 \%$ residential, $11 \%-21 \%$ nonresidential), as shown in Figure 1.

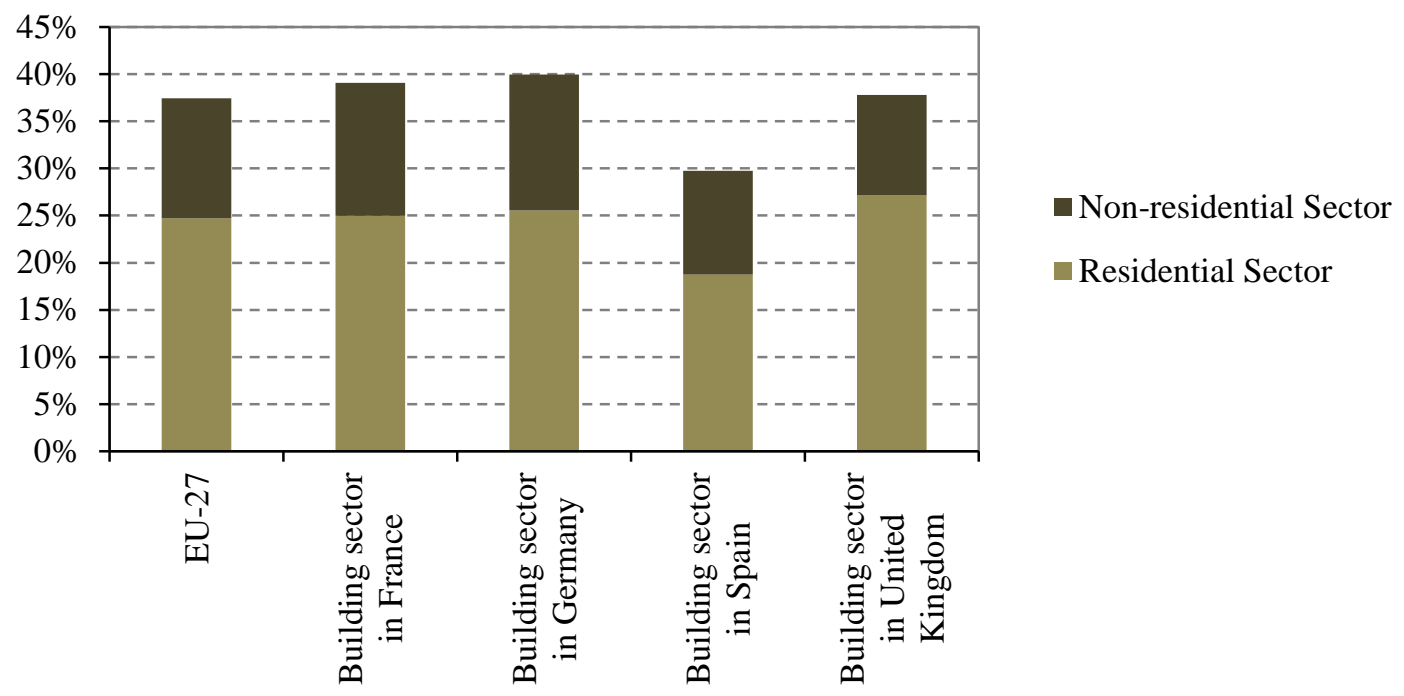

Figure 1. Percentage of residential and non-residential buildings in the final total energy consumption (i.e. all sectors) of the EU-28 and selected MSs. 2011 data from the Eurostat database [24].

This study assesses the possibility of describing the EU building stock for the purpose of forming a basis for analyzing the effect and costs of applying different energy conservation measures (ECMs) to the entire EU building stock ${ }^{3}$ starting with key member states. More specifically, the aims are as follows:

A. To review the existing building stock data for EU, identifying key issues and main data gaps for the purpose of defining archetype buildings

B. To describe a methodology for building stock aggregation applicable to selected EU countries and to the residential and non-residential sectors

C. To apply and evaluate the methodology by describing and aggregating building stocks of four selected EU countries, then comparing the modelled energy use in the stocks with the statistical data available.

The four MSs selected for the study include France, Germany, Spain and the UK which together account for $58 \%$ and $52 \%$, respectively, of the final energy demand and $\mathrm{CO}_{2}$ emissions of buildings in EU-28, as shown in Figure 2. Since they belong to each of the EU climate zones given in [22][23], they are also representative of all EU climates. In accomplishing all three aims, a step forward is made by means of structuring and compiling

\footnotetext{
${ }^{1}$ All the ranges given in this paragraph cover the percentages given in the databases [24][34] for EU-27 (as a total) and for the six most densely populated countries: France, Germany, Italy, Poland, Spain and the UK. Thus, there may be MSs for which the percentages differ from the ranges given here. 2011 data from the Eurostat database [24].

${ }^{2}$ Year 2011 data from the Odyssee database [34].

3 The authors are currently working on an analysis of the potentials and costs for energy saving and corresponding $\mathrm{CO}_{2}$ emission reductions for Spain [113] and on similar studies for the three other countries investigated. Since these works are not yet available, for an application of the modeling methodology to analyze energy use of residential buildings in an EU country not included in this paper (Sweden), see [114].
} 
the information, as well as defining a methodology to be used in building stock modeling with the above geographical and sectorial scope.

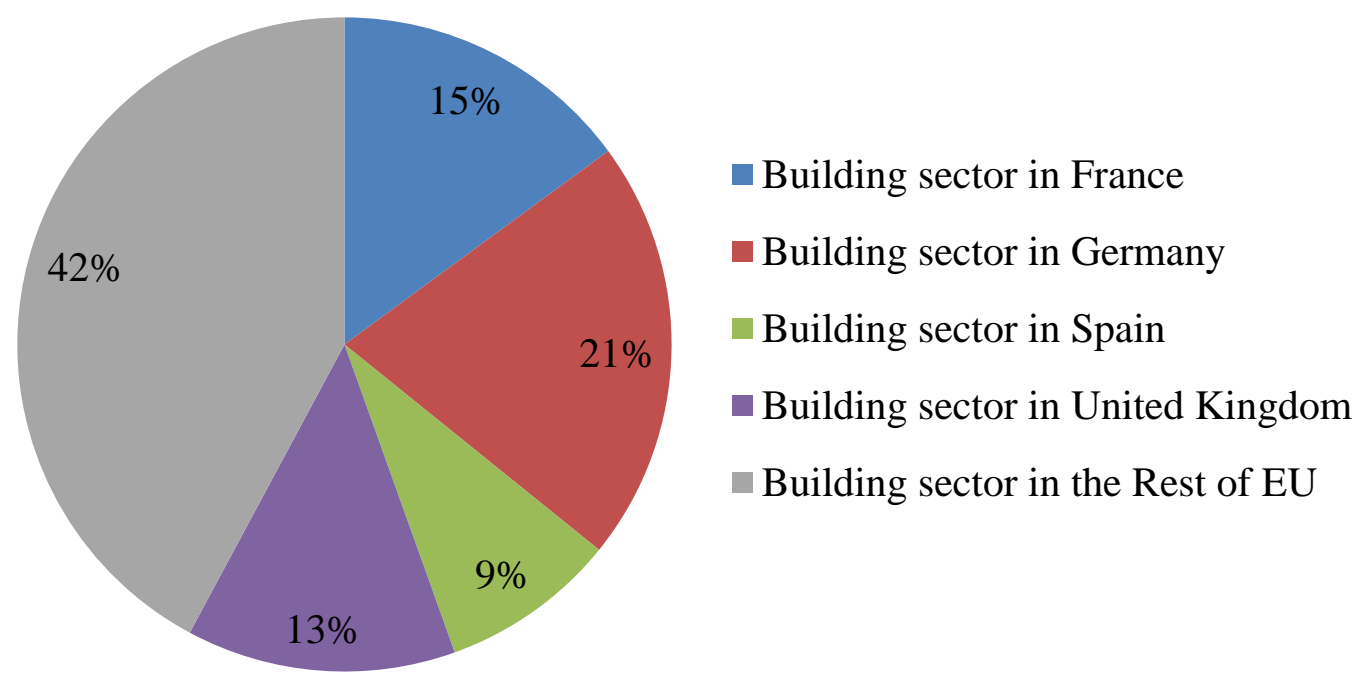

Figure 2. Share of the buildings of the four selected MSs in the final energy consumption of the EU-28 building sector (12831 TWh for residential and non-residential). 2011 data from the Eurostat database [24].

The following section of the paper addresses Aim A by reviewing building stock data and availability, providing a framework of definitions to be used throughout the paper. Section 2 presents the methodology for building stock aggregation, which is implemented in four selected EU countries; thus, this section addresses Aims B and C. Section 3 focuses on Aim C by giving a cross-country comparison of the building stock with respect to the building characteristics determining the energy demand. Section 4 discusses the results and Section 5 summarizes the findings with respect to the three aims cited above.

\subsection{Building stock data and availability}

Building stocks are generally divided into Residential (R), also called domestic or household sector, and Non-Residential (NR) buildings, also known as the tertiary or services sector. In the $\mathrm{R}$ sector, due to the constant transferring between these categories [25], allocations of main, secondary residences and vacant units are difficult to analyze. However, since there has been greater political attention paid to the $\mathrm{R}$ sector, especially in social housing [1], there are generally better statistics and knowledge on the $\mathrm{R}$ sector than on the NR sector. The NR sector has until recently mostly been documented in terms of isolated buildings for technical or cultural reasons (public buildings, industrial monuments, etc.), with the primary focus on buildings that are perceived as individually outstanding works of art [1]. Information available on the building stock has typically been gathered through two basic approaches:

- Census data, compiled for the establishment of a register of new building construction statistics. This type of register includes all new buildings but generally provides only basic information on the stock based on the designed construction project, such as the use of the building, the number of buildings or area. Such information is typically reported in national and subsequently international statistics. 
- Surveys, which are additional studies of the existing buildings through a number of selected buildings carried out with a specific purpose. Surveys provide a wide range of post-occupancy information about buildings, including their technical characteristics, fuel usage and occupant behaviors. Such information is required for the categorization of the stock and is a prerequisite for modelling energy use in the building stock. As a consequence, the countries that have assessed energy-saving and $\mathrm{CO}_{2}$-mitigation potentials have conducted major surveys of their building stocks, e.g., the UK [26], Scotland [27], Belgium [28], and Sweden [29].

Individual billing data and sub-metering may also be available and can be used as complementary information for characterizing building stocks. In recent years, energy certificates [30][31][32] and other information linked to geographical information systems [33] have appeared as additional means of data gathering, although mostly on a regional scale.

Data from the above approaches is compiled on the EU and international levels and three readily accessible databases provide data on the building sector, namely Eurostat [24], ODYSSEE [34], and the Greenhouse Gas and Air Pollution Interactions and Synergies (GAINS) Database [35]. These databases are updated on a regular basis and their main contents are summarized in Table 1. It is clear from the table that Odyssee provides the most complete dataset, including energy consumption for R and NR buildings per fuel and end use. However, not all data categories are included in the database. Eurostat provides only final energy consumption for R and NR buildings and is quite similar to corresponding data by Odyssee. The GAINS Database also includes data disaggregated by single- and multi-family dwellings, as well as data projections according to some scenario-based assumptions. In all cases, data on $\mathrm{CO}_{2}$ emissions are only given on an aggregated level; e.g. Eurostat only gives total greenhouse gas emissions (GHG) (in $\mathrm{CO}_{2} \mathrm{eq}$ ) with no details for the building sector. Another database, the MURE II Policy Database [36], provides information on energy efficiency policies and measures carried out in the MSs of the EU, thus compiling all building regulation codes in force in each MS.

In addition to these databases, some European projects (e.g. EPA-NR [37], EL-TERTIARY [38], and TABULA [21]), have compiled the information available on the building stock of a given country or set of countries. Ó Broin [39] has mapped the available data, indicators, and models related to the energy demands of European buildings. Pérez-Lombard et al. [6] have reviewed the data on energy use in buildings worldwide over the past 30 years (not continuously but in snapshots when the information became available). The recent BPIE Data Hub [40] is an open data portal for statistical data on the European building stock and includes all countries. Data are to be presented according to categories, such as building stock inventory, building stock performance and climatic zones, as well as different building types and owner profiles. However, the current BPIE Data Hub Portal still does not provide data for all categories. Although these studies and databases listed in Table 1 provide a valuable overview of the EU building stock, until recently the data could not be used directly for an archetype-based modelling of the energy performance of the stock because of the lack of physical description of the buildings required for such an analysis and because there has been no quantification of the number of buildings in the building stock. However, TABULA and Data Hub are now updated on a regular basis and their contents have significantly increased by the end of 2013. Yet, these data were not available at the time when the present work was carried out (2010-2013) and, thus, could not be applied here. 
Table 1. Summary of international data sources for the energy consumption levels and characteristics of the European building sector.

\begin{tabular}{|c|c|c|c|}
\hline & Odyssee[ 34] & Eurostat[24] & GAINS[35] \\
\hline Years included & From 1980 & From 1990 & $2005-30$ \\
\hline $\begin{array}{l}\text { Building characteristics } \\
\text { Stock of dwellings } \\
\text { Total floor area } \\
\text { Floor area of dwellings (average) }\end{array}$ & $\begin{array}{l}\text { Yes }^{(1,2,3,4)} \\
\text { Yes }^{(1,3,5,6)} \\
\text { Yes }^{(1,3)}\end{array}$ & & $\begin{array}{l}\text { Yes }^{(1,3)} \\
\text { Yes }^{(1,3)}\end{array}$ \\
\hline $\begin{array}{l}\text { Energy consumption levels } \\
\text { Final energy consumption, residential sector } \\
\text { Final energy consumption, tertiary sector }\end{array}$ & $\begin{array}{l}\text { Yes }^{(7,8,9)} \\
\text { Yes }^{(5,7,9)}\end{array}$ & $\begin{array}{l}\text { Yes }^{(9)} \\
\text { Yes }^{(9)}\end{array}$ & $\begin{array}{l}\text { Yes }^{(3,10,11)} \\
\text { Yes }^{(8,10,12)}\end{array}$ \\
\hline $\begin{array}{l}\mathrm{CO}_{2} \text { emissions } \\
\mathrm{CO}_{2} \text { emissions } \\
\text { Total } \mathrm{CO}_{2} \text { emissions (with electricity) }\end{array}$ & $\begin{array}{l}\text { Yes }^{(6)} \\
\text { Yes }^{(6)}\end{array}$ & & $\begin{array}{l}\text { Yes } \\
\text { Yes }\end{array}$ \\
\hline $\begin{array}{l}(1) \text { Data provided disaggregated into single-fan } \\
{ }^{(2)} \text { Data provided disaggregated into individual } \\
\text { oil/coal/gas/district heating/electric/wood spa } \\
\text { (3) Data provided disaggregated into existing a } \\
{ }^{(4)} \text { Only permanently occupied dwellings. } \\
{ }^{(5)} \text { Data provided disaggregated into hotels/ res } \\
\text { administration, private services, offices and tr } \\
{ }^{(6)} \text { Data provided disaggregated into household } \\
{ }^{(7)} \text { Data provided disaggregated into space hea } \\
{ }^{(8)} \text { Data provided disaggregated into coal, oil, } \\
{ }^{(9)} \text { Data provided also with climatic correction } \\
{ }^{(10)} \text { Data provided disaggregated into space hea } \\
{ }^{(11)} \text { Data provided disaggregated into cooling a } \\
{ }^{(12)} \text { Data provided disaggregated into cooling, }\end{array}$ & $\begin{array}{l}\text { dwellings and } 1 \\
\text { lective central } 1 \\
\text { eating. } \\
\text { ew. } \\
\text { ants, health anc } \\
\text { (wholesale and } \\
\text { d services. } \\
\text { hot water and } \\
\text { heat, wood and } \\
\text { and hot water } \\
\text { leating. } \\
\text { ing and ventilat }\end{array}$ & $\begin{array}{l}\text { mily dwellings } \\
\text { and room heat } \\
\text { actions, educa } \\
\text { g. } \\
\text { city. } \\
\text { g and applianc }\end{array}$ & $\begin{array}{l}\text { well as } \\
\text { earch, }\end{array}$ \\
\hline
\end{tabular}

\section{METHODOLOGY FOR BUILDING STOCK AGGREGATION}

The description of a building stock through archetype buildings proposed in this study follows four steps: segmentation, characterization, quantification and validation of the final energy demand in the building stock for a reference year. For the latter, a detailed and dynamic Building Stock Model is used which was previously validated as described in [41]. Data were compiled through several surveys conducted on a country basis, for which corresponding reports are available for downloading [42][43][44][45].

\subsection{Segmentation}

In the segmentation process, the number of archetype buildings required to represent the building stock of the country is determined. The number of archetype buildings is obtained from the combination of the different segmentation criteria:

- building type, defined from the use of the building, its layout (one or several floors) and the way it is attached to neighbouring buildings (e.g. detached, semi-detached or terrace houses);

- construction year, determined from the updates of the building regulation codes but also according to historical events and changes in construction technologies;

- main heating system; and

- climate zone (within a country), defined in accordance to the climate zoning suggested for winter periods in the building regulation codes. Meteorological data from the most densely populated city in the climate zone is considered representative of the climate in the zone and is generated by Meteonorm [46]. 
It is estimated that these criteria provide a good representation of the energy demand of the buildings. Besides, they facilitate data compilation (i.e. matching the form of data sources) as identified in the literature [9][13][14][20][47][48][49]. The segmentation was applied to both $\mathrm{R}$ and NR buildings in all countries studied, except for Germany where the R stock alone was included. Table 2 summarizes the archetype buildings obtained for each county.

Table 2. Segmentation categories and resulting number of archetype buildings obtained for the four countries investigated. $C$, commercial; L, leisure; MFD, multifamily dwelling; NR, non-residential; $O$, office; $R$, residential; $S C L$, sports, culture and leisure; SFD, single-family dwelling; $T$, terraced house; $X$, other.

\begin{tabular}{|c|c|c|c|c|}
\hline Categories & $\begin{array}{l}\text { France } \\
99 \text { archetypes }\end{array}$ & $\begin{array}{l}\text { Germany } \\
122 \text { R archetypes }\end{array}$ & $\begin{array}{l}\text { Spain } \\
120 \text { archetypes }\end{array}$ & $\begin{array}{l}\text { UK } \\
252 \text { archetypes }\end{array}$ \\
\hline $\begin{array}{l}\text { Building } \\
\text { type }\end{array}$ & $\begin{array}{l}3 \text { R[10]: SFD, } \\
\text { private and public } \\
\text { MFDs; } \\
5 \text { NR [50][51]: C, } \\
\text { E, H, O, SLC }\end{array}$ & $\begin{array}{l}5 \text { [54]: } \mathrm{SFD}^{3}, \text { prefabricated } \\
\text { houses, T, MFD } 4, \text { MFD }<10 \\
\text { floors, MFD }>10 \text { floors } 5\end{array}$ & $\begin{array}{l}2 \text { R: SFD, MFD; } \\
4 \text { NR: C, SLC, } \\
\text { O, X. }\end{array}$ & $\begin{array}{l}6 \mathrm{R} \text { [56]: detached, semi- } \\
\text { detached, T, bungalow; } 3 \\
\text { NR [57]: O, warehouses, } \\
\text { retail }^{10}\end{array}$ \\
\hline $\begin{array}{l}\text { Construction } \\
\text { year }\end{array}$ & $\begin{array}{l}3 \text { R [10]: before } \\
1975 \text {, before } \\
1975 \text { refurbished, } \\
\text { after } 1975 ; \\
3 \text { NR [52][53]: } \\
\text { before } 1977, \\
1977-2000, \text { after } \\
2000\end{array}$ & $\begin{array}{l}\text { 10: before } 1918^{6} \text {, } \\
\text { framework buildings before } \\
1918,1919-48,1949-57 \\
1958-68,1969-79,1980-83 \text {, } \\
1984-94,1995-2002,2003- \\
09\end{array}$ & $\begin{array}{l}\text { 4: before } 1975, \\
1975-79,1980- \\
2005,2006-08^{9}\end{array}$ & $\begin{array}{l}7[58][59][60][61] \text { : before } \\
1985,1986-1991,1992-95, \\
1996-2002,2003-06,2007- \\
10 \text {, and after } 2010\end{array}$ \\
\hline $\begin{array}{l}\text { Heating } \\
\text { system }\end{array}$ & $\begin{array}{l}2 \text { R [10]: electric } \\
\text { heating, other } \\
\text { source for } \\
\text { heating }^{2}\end{array}$ & Non-applicable $^{7}$ & Non-applicable $^{7}$ & $\begin{array}{l}2[56] \text { : central and non- } \\
\text { central }^{11}\end{array}$ \\
\hline Climate zone & $\begin{array}{l}3 \text { (H1to H3) [52]: } \\
\text { Paris, Toulouse, } \\
\text { Marseille }\end{array}$ & 3: Essen, Stuttgart, Munich ${ }^{8}$ & $\begin{array}{l}5 \text { (A to E) [55]: } \\
\text { Málaga, Seville, } \\
\text { Barcelona, } \\
\text { Madrid, Burgos }\end{array}$ & $\begin{array}{l}4 \text { [62]: London, } \\
\text { Birmingham, Newcastle, } \\
\text { Glasgow }\end{array}$ \\
\hline \multicolumn{5}{|c|}{$\begin{array}{l}\text { (1) Which account for } 80 \% \text { of the final energy use of the NR sector in this country. } \\
\text { (2) For NR buildings there are no data available that would allow a division by category with respect to the } \\
\text { sources of energy for heating purposes. } \\
{ }^{(3)} \text { Including two-family dwellings. } \\
{ }^{(4)} \text { With maximal four floors and eight to ten apartments. } \\
{ }^{(5)} \text { Mostly from the } 1960 \text { s and } 1970 \mathrm{~s} \text {. } \\
{ }^{(6)} \text { Except framework buildings. } \\
{ }^{(7)} \text { Data availability did not allow a segmentation of the building stock according to their type of heating system. } \\
{ }^{(8)} \text { Found by adjusting the four recommended zones for calculating the heating load after the DIN EN } 12831 \text { to the } \\
\text { political division of the territory in sixteen states [33]. } \\
{ }^{(9)} \text { This last period of construction is only applicable to the NR sector. } \\
{ }^{(10)} \text { These NR building types are known as the Valuation Office's bulk classes and cover about } 70 \% \text { of all ratable NR } \\
\text { buildings, but exclude for instance hospitals, schools, churches, etc. } \\
{ }^{(11)} \text { Assumed that premises which currently have non-central heating system are all built before } 1985 \text {. The average } \\
\text { internal temperature for centrally heated dwellings is assumed to be } 17.5^{\circ} \mathrm{C} \text { while it is } 14^{\circ} \mathrm{C} \text { for non-centrally heated } \\
\text { premises. }\end{array}$} \\
\hline
\end{tabular}

\subsection{Characterization}

In the characterization step, each archetype is described by its technical characteristics (i.e. 23 inputs as listed in [41]) based on the parameters from the segmentation provided in Table 3. The four countries include a total of 593 archetype buildings. Although all inputs and assumptions are of relevance, such a matrix of data is rather extensive and would be too 
comprehensive to fit into a journal paper. Instead, a summary of a common procedure for gathering all the data as well as the sources used, on a country basis, is provided. In addition, selected country-specific values of the data are also provided for the purpose of understanding the levels of detailing as well as the differences between the countries. Further details on the characterization of the archetypes, including values for all inputs, are given in the corresponding country reports [42][43][44][45].

Table 3. Segmentation categories and relevant building data depending on the category.

\begin{tabular}{cc}
\hline Categories & Relevant building data dependent on the category \\
\hline Building type & Effective heat capacity of the building \\
Floor area & External surface area \\
Internal gains \\
Minimum desired indoor temperature \\
Maximum desired indoor temperature \\
Sanitary ventilation rate \\
Window area \\
Construction year \\
Average U-value of the building \\
Heating system & Ventilation rate \\
& Indoor temperatures \\
Climate zone & Fuels used \\
& Average U-value of the building \\
Outdoor climate data
\end{tabular}

Reports from official authorities responsible for dwellings (e.g. Ministry of Dwellings/Energy/Environment in the four countries) provide information on the physical characteristics of the buildings. National building energy codes have been used to determine the indoor conditions and thermal properties of the building envelope, i.e., the period of construction is translated into U-values according to the building codes on a country-basis (seen mainly from the construction year in Table 2). The reliance on the building codes implies that the buildings have been constructed in each period of time according to the regulations and that they are operated according to their technical requirements; nevertheless, the literature does not provide any systematic check on regulatory compliance. The nature of the task is data intensive; thus, the references in this section are numerous but provided for transparency; furthermore, mostly national sources and other branch-specific journals have been used to obtain building data. Unknown surfaces of envelope (such as facades, cellars, roofs and windows) and building geometry are obtained according to the so-called 3CL-DPE Method [63], based on the floor area heated, the number of levels/floors, assumptions of the building form and attachment to neighbouring buildings' of each building as defined by the 3CL-DPE Method. The fuel use is allocated to the R and NR archetypes separately. In all four countries, it has been possible to separately allocate different fuels and technologies for space heating and hot water. Both for the fuel types and the efficiencies of the different heating technologies, data were found only at level of aggregation that would not allow for differentiation of each archetype.

For French buildings, U-values are determined for the different construction periods according to building regulations; for the R sector from [64][65][66] and for the NR sector from [67]. There are no data for the U-values of the oldest $\mathrm{R}$ and NR buildings per climate zone, and the U-values of the $\mathrm{H} 3$ climate zone are assumed to be $15 \%$ higher than those of the other two zones [68]. Ventilation rates for R buildings are between 0.23 and $0.51 \mathrm{l} / \mathrm{s} / \mathrm{m}^{2}$ as 
extracted from [67], and for NR buildings these are between 0.37 and $1.47 \mathrm{1} / \mathrm{s} / \mathrm{m}^{2}$ from [43] [68][69]. Since no data have been found for France, natural ventilation rates for $\mathrm{R}$ buildings are $0.40 \mathrm{l} / \mathrm{s} / \mathrm{m}^{2}$ as calculated according to the 3CL Method [10] and for the NR buildings from [43]. Heat gains from occupants are calculated considering metabolic gains at low activity (i.e. sitting) [70], except for the sports, culture and leisure (SCL) buildings where heat gains from occupants correspond to higher activity levels. Heat gains from lighting, equal to their electricity consumption, for R buildings are calculated by adding $3 \mathrm{~W} / \mathrm{m}^{2}$ to each $100 \mathrm{lux}$ of installed illuminance [67], with a minimum illuminance of 300 lux required in households (since the heated floor area of the household is different for each archetype, the heat gain also differs between archetypes). For NR buildings, heat gains from lighting range from 3.1 to $11.5 \mathrm{~W} / \mathrm{m}^{2}$ and are calculated from the lighting consumption [71] assuming the operating schedules and occupancy patterns shown in [43]. Heat gains from appliances in R buildings are $2.1 \mathrm{~W} / \mathrm{m}^{2}$ for an average SFD of $103.8 \mathrm{~m}^{2}$ and 3.4 for an average MFD of $66.0 \mathrm{~m}^{2}$ [21]. For NR buildings, gains from appliances range from 1.1 to $4.7 \mathrm{~W} / \mathrm{m}^{2}$ [44][72]. Due to the lack of data, building materials in France are assumed to be similar to those of Catalan buildings because of their proximity and common building technology [73]. The distribution of energy sources within $\mathrm{R}$ buildings is taken from [74], where the percentages of each heating system per climate zone are specified. Thereafter, these values have been separated into SFD and MFD according to the division proposed by [75]. Regarding NR buildings, the percentages for climate zone $\mathrm{H} 1$ are taken for offices $(\mathrm{O})$ and commercial (C) buildings from [76], and for educational (E) buildings from [77]. The remaining archetype buildings have the same average shares of $47.5 \%$ electricity, $28.1 \%$ gas, $19.8 \%$ oil, and $4.6 \%$ other fuels as provided by [78]. Data regarding the efficiency of the boilers installed in the buildings were lacking at a national level; therefore, average values were considered based on [79].

For German R buildings, all U-values are taken from [54]. In Germany, natural ventilation is prevalent for supplying fresh air to the buildings. The share of buildings with a mechanical ventilation system is less than $1.5 \%$ and only around half of them have heat recovery (the latter is disregarded). Additionally, $10 \%$ of the newly constructed buildings are equipped with ventilation systems [80]. Sanitary (natural) ventilation rates ${ }^{4}$ are between $0.60 \mathrm{ACH}$ and 0.85 $\mathrm{ACH}$, depending on the construction year. Values for heat gains from appliances and occupancy range, respectively, were between $1.78 \mathrm{~W} / \mathrm{m}^{2}$ and $2.66 \mathrm{~W} / \mathrm{m}^{2}$ and between 1.11 $\mathrm{W} / \mathrm{m}^{2}$ and $2.00 \mathrm{~W} / \mathrm{m}^{2}$ for the different building types according to [81]. Heat gain from lighting is $0.27 \mathrm{~W} / \mathrm{m}^{2}$ for all buildings, calculated from the energy use for lighting per person and per year [82], as well as the average number of person per household given in Eurostat [24] and the average floor area of a German dwelling [80]. Hot water demand is between 1.16 $\mathrm{W} / \mathrm{m}^{2}$ and $3.38 \mathrm{~W} / \mathrm{m}^{2}$ for the different building types. The distribution of different types of heat and hot water generators/producers was acquired from [80]. The efficiencies of the heating and hot water systems were extracted from [83].

For Spanish buildings, the period of construction was translated into U-values according to the building codes [55][84][85]; for buildings constructed before the implementation of the first thermal regulation in 1975, the average U-value is based on [20][86]. Ventilation rates for $\mathrm{R}$ buildings are between 0.42 and $0.51 \mathrm{1} / \mathrm{s} / \mathrm{m}^{2}$ as taken from [55] and for buildings constructed before 1975 these are taken as the infiltration rate of $4 \mathrm{ACH}$ reported in [55]; for NR buildings, between 0.55 and $0.83 \mathrm{l} / \mathrm{s} / \mathrm{m}^{2}$ from [86]. Heat gains from occupants, lighting

\footnotetext{
${ }^{4}$ Here, ventilation rates are given the units provided in the original reference $\left(\mathrm{ACH}\right.$ or $\left.1 / \mathrm{s} / \mathrm{m}^{2}\right)$. Transformation between these two units requires some assumptions with respect to the volume of indoor air (thus heated floor area) that would distort the original data.
} 
and appliances were extracted from the appendices of the Spanish building code [87]. Average hot water demands for $\mathrm{R}$ buildings are provided in [55] and corresponding values for NR buildings are based on [73]. Building materials are similar to those of Catalan buildings [73]. Fuel shares for heating and hot water demand are extracted from [88]. A certain share of Spanish R buildings without any heating system [89] is assumed for each climate zone (A: 55\%, B: $13 \%$, C: $14 \%$, D: $8 \%$; E: $8 \%$ ).

The U-values of the buildings in the $\mathbf{U K}$ are based on the requirements of building code Part $\mathrm{L}$ during each time period. The U-values for the buildings constructed before 1985 are taken from [15][16][17]. The sanitary ventilation rate for $\mathrm{R}$ buildings is $0.3 \mathrm{l} / \mathrm{s} / \mathrm{m}^{2}$ [86][90] and for NR buildings, these range from 0.9 to $1.21 / \mathrm{s} / \mathrm{m}^{2}$ (based on the average rate per person and the required air changes per hour [71]). NR buildings built after 1985 are assumed to have a mechanical ventilation system and after 1990, they are also assumed to have a heat recovery system. Natural ventilation rates for R buildings built after 1996 meet legislative requirements [58][59][60][61] and the ventilation rates for older buildings are taken from [17]; for NR buildings, infiltration rates span from 0.5 to $1.0 \mathrm{ACH}$ [45]. Average heat gain from lighting for $\mathrm{R}$ buildings is $0.9 \mathrm{~W} / \mathrm{m}^{2}$ (calculated from [15] and in accordance to [45]); for NR buildings, heat gains from lighting range from 4.3 to $10.8 \mathrm{~W} / \mathrm{m}^{2}$ [91]. Average heat gains from appliances for $\mathrm{R}$ buildings range from 2.4 to $5.5 \mathrm{~W} / \mathrm{m}^{2}$ as calculated from [15]; for NR buildings, they are $3.0 \mathrm{~W} / \mathrm{m}^{2}$ for warehouses calculated from [59], for offices $4.3 \mathrm{~W} / \mathrm{m}^{2}$ and for retail $7.3 \mathrm{~W} / \mathrm{m}^{2}$ [45]. Average heat gains of occupants of $\mathrm{R}$ buildings range from 0.5 to 1.6 $\mathrm{W} / \mathrm{m}^{2}$ (calculated based on the number of persons per household [56] and the metabolic heat gain from occupants); for NR buildings, these range from 1.39 to $3.31 \mathrm{~W} / \mathrm{m}^{2}$ as calculated from the occupancy of warehouses, offices and retail [45]. Average hot water demand for R buildings is 103 litres per household per day for all dwelling types [17]; for NR buildings, this range spans from 0.9 to $1.6 \mathrm{~W} / \mathrm{m}^{2}$ [91]. For the UK, different fuel shares have been assigned to R buildings, depending on whether they have central or non-central heating [56], and to NR buildings, the fuel mix is based on [92]. Efficiency of the boilers (2006 to 2010) is cited based on [17][56][93][94].

\subsection{Quantification}

The quantification step determines the distribution of archetype buildings in order to be representative of the building stock, i.e. the so-called weighting coefficient is the number of buildings of the stock which are represented by each archetype building. National statistics are generally sufficient to quantify the number of buildings and their total floor area. When the number of buildings and heated floor areas was not available for each year, it has been constructed from information by using construction and demolition rates for a precise year. With respect the heated floor areas, the sources usually do not specify if gross or net areas are involved.

In France the number of buildings is taken from [14][95]. The number of social dwellings existing in 1975 is given in [96] and the existing public MFD in 2007 is provided in [97]. A refurbishment rate of 45,000 renovations per year has been assumed based on the figure for the period 1977-2005 given in [98]. The number of NR buildings is calculated from the total existing surface of NR buildings given in [37], per construction period [99] and appliying annual growth rates [100], and the average heated floor areas per building. These average heated floor areas per building for R buildings are given in [66]; for NR buildings, floor areas for NR-C and NR-E are calculated based on the average heated floor area in 2004 found in [101]; for NR-Hand for NR-SCL from [64]. The number of R buildings in Germany and their heated floor areas are given for all archetype buildings in [102]. The adjustments required to 
separately quantify high towers and apartment blocks (which Diefenbach and Loga [102] consider to be one building type) are presented in [44]. The number of Spanish buildings and their heated floor areas are taken from [89][103]. Demolition rates related to number of buildings and per floor areas are $0.13 \%$ and $0.24 \%$, respectively, and are calculated from [104]. Finally, the total number of buildings in the UK per region and time period has been derived from the BRE's domestic and non-domestic fact files [45][57].

\subsection{Validation of the final energy demand for a reference year}

To validate the building stock aggregation, the final energy demand is calculated using the defined archetype buildings as input to the model and comparing the results with corresponding values of energy use found in national and international statistics for a particular reference year. The energy demand is calculated using the Energy, Carbon and Cost Assessment of Building Stocks (ECCABS) Model [41]. Since in the EU, space heating remains the most relevant energy demand in buildings and since it is difficult to obtain accurate statistics of cooling demand (i.e. partly included in electricity use), cooling demand ${ }^{5}$ has not been included in the analysis. Although for the building-stock modelling such as in this paper the validation is only possible at an aggregated level and there are generally no data per end use or building type, the accuracy of the energy balance for one building (in the ECCABS Building Stock Model) has been validated previously by comparative and empirical means for an existing Swedish residential building and a Spanish office building [41]. This indicates that the accuracy of the model should be sufficient for studying the energy use of the entire national buildings stocks for which the critical part are access to available statistics and input data, rather than the level of detail in the modelling. In any case, if snapshots of data exist for a particular end use or building type, these data are presented further down in this section for comparison. In order to start compensating for this lack of data, in Section 3.1 modelling data from this work is provided homogeneously for all countries and comprehensively for all end uses and building types.

The ECCABS Building Stock Model is dynamic and detailed (according to the classification of calculation procedures in EN ISO 13790) and is a bottom-up engineering model (according to the classification by Swan and Ugursal [2]). The main advantage of this method over the monthly/quasi-steady-state method (as defined in EN ISO 13790) is that the hourly time intervals enable direct input of hourly patterns of heating and ventilation, as well as of heat gains (occupants, lighting and appliances). Unlike steady-state methods, such as relying on heating degree days, this model allows for the calculation of indoor temperature and based on this measurement, the exact heating and ventilation requirements (indoor temperature is generally assumed as a constant in monthly/quasi-steady-state methods). Since the final aim of the archetypes is to provide a basis for investigating ECMs, a dynamic and detailed model is required in order to (1) investigate ECMs that involve building site management and user behavior (i.e. demand side management) and (2) analyze the effects of applying ECMs on indoor temperature. The model consists of two parts: a Simulink model, which solves the energy balance for buildings, and a code written in Matlab [105], which handles the input and output data from the Simulink model. The net energy demand of each representative building is calculated based on the physical and thermal properties of the buildings and their thermal inertia, a description of the heating and ventilation systems, energy usage and climate

\footnotetext{
${ }^{5}$ Although cooling demand is calculated in the model, the model output has not been used in this paper. For an example of how the modeling methodology used here, including the cooling demand, has been used to study the impact of climate change on the energy performances of buildings in Stockholm, see [115].
} 
conditions. The energy balance is calculated every hour and the results are summed up to give the annual values of all energy flows (transmission, radiation, ventilation and internal gains), as well as the resulting net and final energy demands per end use and building type. Each building is treated as one thermal zone. A full description of the Building Stock Model is available [41].

As seen from Table 4, the difference between the resulting final energy demand as obtained from the ECCABS Model using the archetype buildings of this work and Eurostat [24], Odyssee [34] and Gains [35] statistics range from $-6 \%$ to $+2 \%$, depending on the country. Although international statistics yield similar data for each country, national sources report data that slightly differ from the above sources.

Table 4. Deviation of the resulting final energy demand (TWh) in the reference year as obtained from the modelling using the archetype buildings derived in this study from the corresponding data available in statistics for the different countries studied. The sources used for the comparison are specified in the table.

\begin{tabular}{rrrrr}
\hline Country & Subsector & This work & From statistics & Deviation from statistics \\
\hline France & $\mathrm{R}$ & 454.7 & $472.1[34]$ & $-4 \%$ \\
& & & $460.0[106]$ & $-4 \%$ \\
Germany & $\mathrm{NR}$ & 191.8 & $188.3[107]$ & $+1 \%$ \\
& $\mathrm{R}$ & 684.2 & $680.0[108]$ & $+1 \%$ \\
Spain & $\mathrm{R}$ & 178.4 & $688.3[109]$ & $-1 \%$ \\
& & & $175.2[24]$ & $+2 \%$ \\
& $\mathrm{NR}$ & 91.9 & $98.6[24]$ & $+2 \%$ \\
& & & $97.7[35]$ & $-6 \%$ \\
UK & $\mathrm{R}$ & 571.8 & $563.7[92]$ & $-5 \%$ \\
& $\mathrm{NR}$ & 81.4 & $79.9[92]$ & $+1 \%$ \\
\hline
\end{tabular}

Data on energy demand disaggregated by end use is only available for France and Germany. For France, ADEME [106] reports final energy demand that, per end use, significantly differs from the results of this study (i.e. demand for heating is $22 \%$ lower than in this study, for hot water $15 \%$ higher, and for electricity $24 \%$ lower) despite the fact that the above reported final total energy demand is similar to the demand obtained here. Yet, there are no details on the methodology applied in [106], and therefore, it has not been possible to find the reason for the simulation discrepancies in this study. For Germany, Statistisches Bundesamt [108] gives a total energy demand that is $3 \%$ higher than our calculations, a hot water demand that is $27 \%$ lower than our results, whereas space heating demand is $14 \%$ higher. The demand reported for appliances and lighting is similar to our results. Considering that the overall agreement is $-6 \%$ to $+2 \%$ as depending on country, and that hot water demand accounts for $7-20 \%$ of the total energy use in the four residential sectors investigated, the comparison appears to be satisfactory.

\section{RESULTS}

The number of subtypes in the categories of building type and construction year differs most greatly between the countries since these reflect historical events, tradition in building styles, changes in construction techniques and building regulation codes, as summarized in Table 2. With respect to the building type, the form of data sources generally allows for a clear differentiation between $\mathrm{R}$ and NR building data. The number of subtypes in each sector required to resolve the building stock differs from the simplest division into only SFD and 
MFD, as in Spain, to the more detailed differentiation of four or five subtypes as required for Germany and the UK. With respect to the number of climate zones within a country, the division required obviously increases with the variations in altitude and latitude within the country and whether there is ocean exposure. The fewer such variations in Germany result in only three weather zones, whereas five weather zones are necessary for Spain.

As indicated in the previous Section 2.2, the characterization of the buildings is mostly based on building code regulations and a wide range of national sources. Typically, significant uncertainties arise during data compilation and validation of building statistics as in the present study [110]. To address to what extent these input uncertainties affect the validation of the aggregated description, the influence of each input/building characteristic on the total energy demand obtained from the modelling is quantified by normalized sensitivity coefficients as proposed by Firth et al. [16]. Normalized sensitivity coefficients $\left(S_{j, i}\right)$ represent the corresponding percentage change in the output variables of the model given a $1 \%$ change in the input, and are calculated according to the equations in page 33 in [16]. Table 5 exemplifies the results of the sensitivity analysis for the residential sector, including the six input parameters with the greatest effect on the energy demand modelled. For all countries, the input value of minimum indoor temperature $\left(\mathrm{T}_{\min }\right)$ has the greatest impact on the energy demand modelled. As commented in Section 2.4, the indoor temperature is calculated every hour. Heating demand is defined as the heating power required to maintain the indoor air temperature above the given level $\mathrm{T}_{\mathrm{min}}$. In the model, the heating system is turned $\mathrm{ON}$ if the indoor air temperature is lower than a minimum indoor temperature. Otherwise, the heating system is turned OFF.

Table 5. Summary of input parameters for $R$ buildings mostly determinant of the final energy demand of the $R$ sector (i.e. with highest normalized sensitivity coefficient $S_{j, i}$ ) as resulting from the sensitivity analysis for the different countries studied.

\begin{tabular}{cccccccc}
\hline France & \multicolumn{2}{c}{ Germany } & \multicolumn{2}{c}{ Spain } & \multicolumn{2}{c}{ UK } \\
Parameter & $S_{j, i}$ & Parameter & $S_{j, i}$ & Parameter & $S_{j, i}$ & Parameter & $S_{j, i}$ \\
\hline $\mathrm{T}_{\min }$ & 1.62 & $\mathrm{~T}_{\min }$ & 1.52 & $\mathrm{~T}_{\min }$ & 2.05 & $\mathrm{~T}_{\min }$ & 1.63 \\
$\mathrm{U}$ & 0.71 & $\mathrm{~S}$ & 0.75 & $\mathrm{~V}_{\mathrm{cn}}$ & 1.82 & $\mathrm{U}$ & 0.88 \\
$\mathrm{~S}$ & 0.71 & $\mathrm{U}$ & 0.75 & $\mathrm{~S}$ & 0.84 & $\mathrm{~S}$ & 0.87 \\
$\mathrm{~A}$ & 0.30 & $\mathrm{~W}_{\mathrm{c}}$ & 0.71 & $\mathrm{U}$ & 0.84 & $\mathrm{~A}$ & 0.21 \\
$\mathrm{~V}_{\mathrm{c}}$ & 0.16 & $\mathrm{~A}$ & 0.45 & $\mathrm{~A}$ & 0.27 & $\mathrm{H}_{\mathrm{w}}$ & 0.20 \\
$\mathrm{H}_{\mathrm{w}}$ & 0.15 & $\mathrm{~V}_{\mathrm{c}}$ & 0.36 & $\mathrm{~S}_{\mathrm{w}}$ & 0.11 & $\mathrm{~W}_{\mathrm{f}}$ & 0.07 \\
\hline
\end{tabular}

As shown in Table 5, the properties of the building envelope have the second highest impact on the energy demand. Such properties naturally include the average U-value of the envelope $(\mathrm{U})$, as well as the surface of the envelope (S) and the characteristics of the windows (i.e. area, $\mathrm{S}_{\mathrm{w}}$, and percentage of window frame, $\left.\mathrm{W}_{\mathrm{f}}\right)$. Finally, hot water demand $\left(\mathrm{H}_{\mathrm{w}}\right)$ is important in the $\mathrm{R}$ sector since it corresponds to $9-20 \%$ of the final total energy demand for the four countries investigated. However, for the NR sector (not shown in Table 5), ventilation and lighting are more relevant than hot water demand; i.e. the normalized sensitivity coefficients $S_{i, j}$ for NR obtained for the ventilation rates range from 0.16 to 0.26 ; for lighting, from 0.11 to 0.15 ; and for appliances, from 0.05 to 0.15 . In summary, the two parameters most determining of energy demand have been defined assuming, for the U-values, that the buildings have been constructed according to the building codes and, for indoor temperatures, that the buildings are operated according to their technical and healthy requirements. In other words, these parameters have not been defined empirically due to data unavailability as described in 
section 2.2., and correspondingly there is considerable uncertainty about the assumed values. In the following paragraphs, modelling assumptions and results with respect to these parameters are presented in greater detail.

Figure 3 illustrates the average annual indoor air temperatures as obtained from the model for the SFD, MFD and NR buildings in the four MSs investigated. The ranges of temperature are limited by the minimum temperatures defined as inputs, generally assumed to correspond to the minimum indoor temperature set by each national building code or regulation. For French $\mathrm{R}$ buildings, the minimum temperature is $19{ }^{\circ} \mathrm{C}$ [111], and for NR buildings, it ranges from 18.5 to $21{ }^{\circ} \mathrm{C}$ for the different buildings types [70]. For German R buildings, the minimum indoor temperature is $18{ }^{\circ} \mathrm{C}$. For Spain, the minimum indoor temperature is $18^{\circ} \mathrm{C}$ for $\mathrm{R}$ buildings [85] and $21^{\circ} \mathrm{C}$ for NR buildings [86]. Finally, for the UK, the minimum indoor temperature is $17.3^{\circ} \mathrm{C}$ and $14.8^{\circ} \mathrm{C}$ for centrally and non-centrally heated $\mathrm{R}$ buildings, respectively [56]. In NR buildings, the recommended temperature for heating and cooling design is $21^{\circ} \mathrm{C}, 20^{\circ} \mathrm{C}$ and $16^{\circ} \mathrm{C}$ for offices, retail and factories, respectively [91]. Applying the assumed minimum temperatures to the ECCABS Model results in an average yearly indoor temperature of $19.3^{\circ} \mathrm{C}$ and an average indoor temperature during the heating season $\left(21^{\text {st }}\right.$ September to $21^{\mathrm{st}}$ March) of $18.3^{\circ} \mathrm{C}$ for the UK R buildings. When only the winter season is considered ( $21^{\text {st }}$ December to $21^{\text {st }}$ March), $17.4{ }^{\circ} \mathrm{C}$ is obtained which is lower than the $19.5^{\circ} \mathrm{C}$ reported by Huebner et al. [112] based on the measured average temperature in living rooms of 248 homes during 92 winter days (November to January); although living rooms usually have the highest temperatures in a house and our temperatures are averages of the temperature for the entire dwelling.

Figure 4 shows the average U-values of the buildings in each country for residential (SFD and MFD) and non-residential buildings, as obtained from modelling the archetypes described in this paper. Since the modelling allows aggregating scattered data, Figure 4 adds to the Uvalues from the literature presented in Section 2.2 their distribution and quantification across the building stocks of the different MSs. In general, the U-values are lower in the colder climate zones and higher in the warmer zones, with Spain and Germany having the highest and lowest average U-values, respectively, for all building types investigated. Eurostat reports the number of annual degree days of reference (DDn/yr) for EU countries as follows: Spain, 2,136; France, 2,250; UK, 3,164; and Germany, 3,749. However, despite featuring the coldest climate, the U-values of German MFDs buildings $\left(1.5 \mathrm{~W} / \mathrm{m}^{2} \mathrm{~K}\right)$ are higher than the corresponding values for UK MFDs $\left(1.2 \mathrm{~W} / \mathrm{m}^{2} \mathrm{~K}\right)$. MFDs buildings in the UK have low average U-values, perhaps due to the fact that residential buildings constructed before 1985 have an average U-value of around $1.3 \mathrm{~W} / \mathrm{m}^{2} \mathrm{~K}$, as reported previously (cf. [45] for a summary of the U-values reported in [17][20][16]). In the other three countries, the older buildings (built before 1985) have U-values $>2.0 \mathrm{~W} / \mathrm{m}^{2} \mathrm{~K}$, with $\mathrm{U}$-values up to $3.5 \mathrm{~W} / \mathrm{m}^{2} \mathrm{~K}$ in France for the oldest public MFDs which are not yet refurbished. Another interesting result is that, despite the similarity in climate between Spain and France, Spanish buildings have significantly higher U-values (i.e., around $1.9 \mathrm{~W} / \mathrm{m}^{2} \mathrm{~K}$ for all building types) than French buildings (i.e., $1.1 \mathrm{~W} / \mathrm{m}^{2} \mathrm{~K}$ for $\mathrm{SFD}, 1.6 \mathrm{~W} / \mathrm{m}^{2} \mathrm{~K}$ for $\mathrm{MFD}$, and $1.3 \mathrm{~W} / \mathrm{m}^{2} \mathrm{~K}$ for $\mathrm{NR}$ ). Therefore, it can be concluded that $\mathrm{U}$-values are not exclusively related to climate type. 

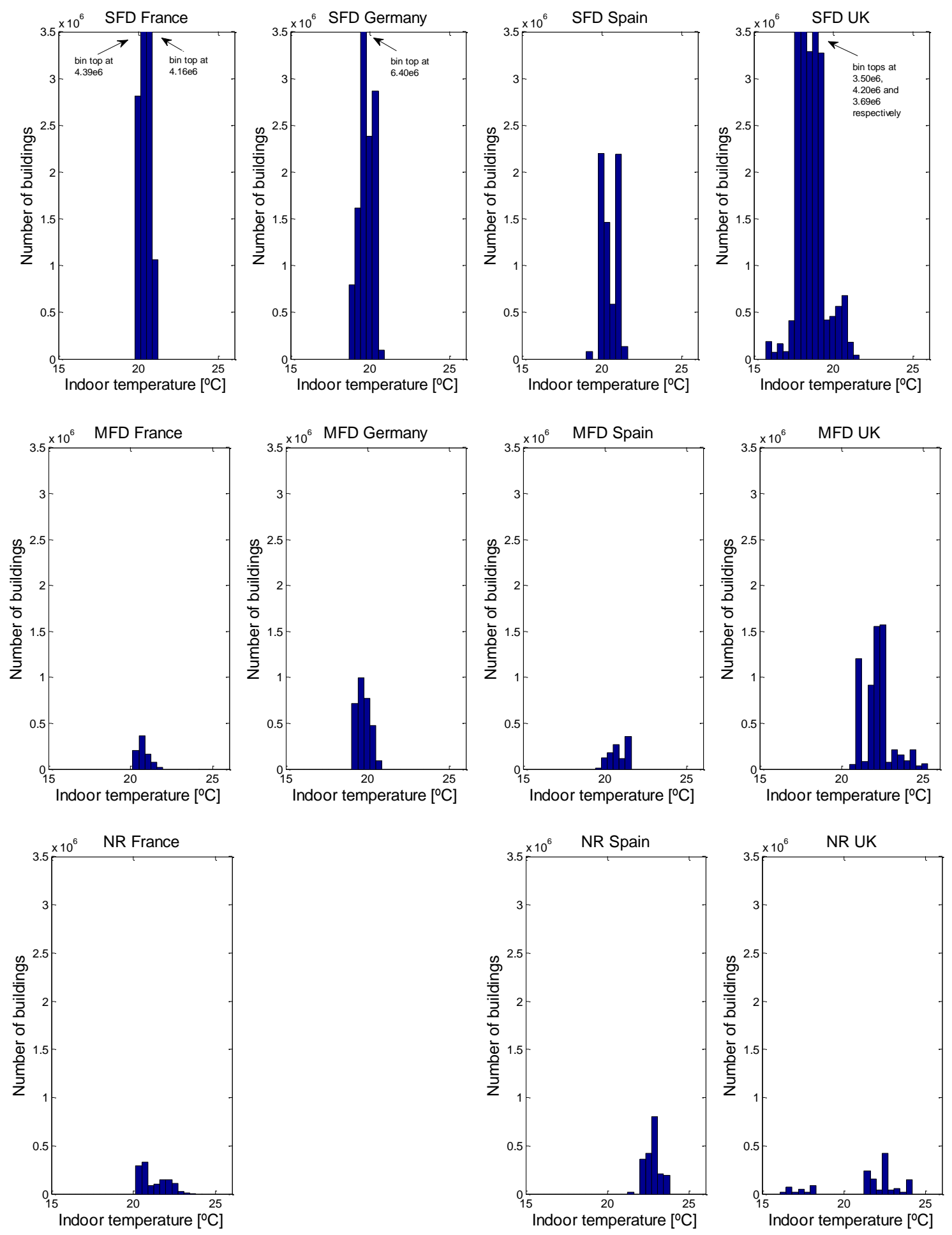

Figure 3. Average annual indoor temperatures obtained from the modelling in this study in the existing building types of the different countries investigated. Bin width is $0.4^{\circ} \mathrm{C}$. 

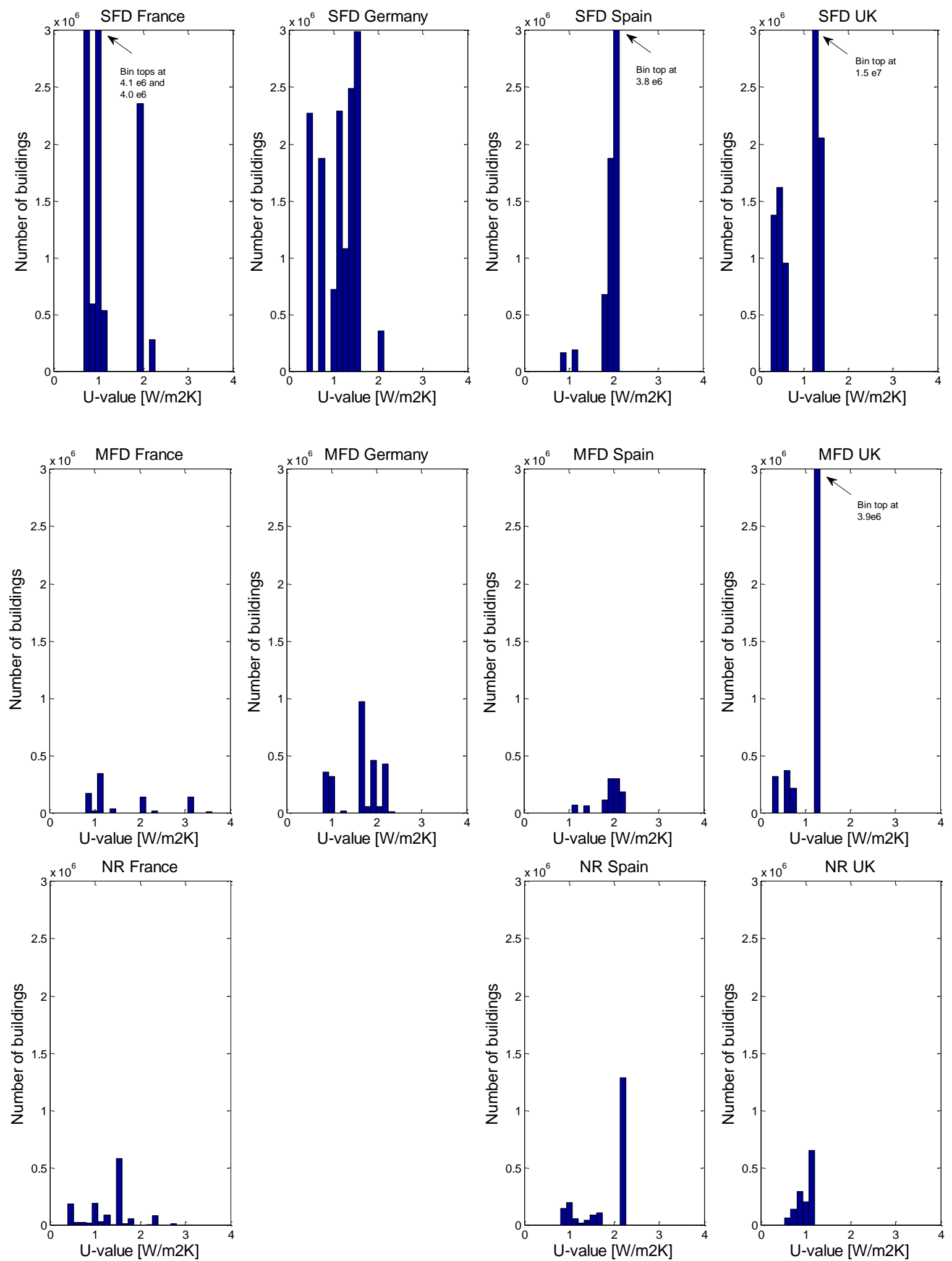

Figure 4. Comparison of the distribution of U-values among the existing building types of the different countries investigated, obtained from the modelling in this work. Bin width is $0.15 \mathrm{~W} / \mathrm{m}^{2} \mathrm{~K}$. 
Tables 6 to 9 summarize the final energy demand obtained by using the archetype buildings of Table 2 as input in the ECCABS Model, presented per building type and end use. The final energy demand of R building shows some correlation with climate, with the Spanish, French, UK and German buildings using on the average $137.8 \mathrm{kWh} / \mathrm{m}^{2}, 200.3 \mathrm{kWh} / \mathrm{m}^{2}, 209.2$ $\mathrm{kWh} / \mathrm{m}^{2}, 242.2 \mathrm{kWh} / \mathrm{m}^{2}$, respectively. In their turn, NR buildings in Spain, France and the UK use $291.8 \mathrm{kWh} / \mathrm{m}^{2}, 252.8 \mathrm{kWh} / \mathrm{m}^{2}$ and $188.4 \mathrm{kWh} / \mathrm{m}^{2}$, respectively. Although further work is needed to understand why the energy demands of $\mathrm{R}$ buildings decrease with a warmer region, while at the same time these energy demands increase for NR buildings, cooling demand might be partially accounted for in the electricity use given as input for NR buildings. Since the share of space heating of the total energy demand ranges from 59\%-82\% in $\mathrm{R}$ buildings in the four countries investigated, the share of electricity use ranges from $11 \%$ to $24 \%$. The latter is much higher in NR buildings than in $\mathrm{R}$ buildings and ranges from 64\%-45\%; while the share of space heating ranges from $34 \%-46 \%$.

Table 6. Final energy demands (in TWh) of the French residential sector in 2005, and for the French non-residential building in 2009 according to end-uses and building subtypes.

\begin{tabular}{|c|c|c|c|c|c|c|c|c|c|c|c|}
\hline End-uses & $R$ & $\begin{array}{l}\mathrm{R} \\
\mathrm{SFD}\end{array}$ & $\begin{array}{c}\mathrm{R}- \\
\text { Private } \\
\mathrm{MFD}\end{array}$ & $\begin{array}{c}\mathrm{R}- \\
\text { Public } \\
\text { MFD }\end{array}$ & $N R$ & $\begin{array}{l}\text { NR- } \\
\mathrm{O}\end{array}$ & $\begin{array}{c}\text { NR- } \\
\mathrm{C}\end{array}$ & $\begin{array}{c}\text { NR- } \\
\mathrm{H}\end{array}$ & $\begin{array}{l}\text { NR- } \\
\text { E }\end{array}$ & $\begin{array}{l}\text { NR- } \\
\text { SCL }\end{array}$ & $T$ \\
\hline Heating & 285.3 & 201.4 & 41.7 & 42.2 & 93.3 & 25.4 & 28.3 & 20.0 & 13.9 & 5.7 & 378.6 \\
\hline Hot water & 74.6 & 41.0 & 21.5 & 12.2 & 18.0 & 2.0 & 3.4 & 3.0 & 4.8 & 4.9 & 92.6 \\
\hline Electricity* & 94.7 & 55.7 & 25.0 & 14.0 & 80.5 & 28.9 & 24.2 & 7.6 & 10.8 & 8.9 & 175.2 \\
\hline TOTAL & 454.7 & 298.1 & 88.2 & 68.4 & 191.8 & 56.2 & 56.0 & 30.6 & 29.4 & 19.5 & 646.5 \\
\hline $\begin{array}{l}\text { Heated floor } \\
\text { Area }\left(\mathrm{Mm}^{2}\right)\end{array}$ & 2269.6 & 1472.4 & 512.0 & 285.1 & 758.3 & 199.7 & 202.7 & 182.3 & 106.5 & 67.0 & 3027.9 \\
\hline
\end{tabular}

*Electricity includes the electricity for electrical appliances, lighting, hydro pumps, fans and air conditioning; R, residential; NR, non-residential; T, residential and non-residential; SFD, single-family dwelling; MFD, multifamily dwelling; O, office; C, commercial; $\mathrm{H}$, health; E, educational, SCL, sports, culture and leisure.

Table 7. Existing heated floor areas and annual final energy demand (in TWh) by end use and building type in the German residential sector (in 2009), as obtained in this work.

\begin{tabular}{ccccccc}
\hline End-uses & \multirow{2}{*}{$R$} & \multirow{2}{*}{-SFD } & \multirow{2}{*}{ R -T } & R - & \multirow{2}{*}{ R -AP } & R - \\
& 560.6 & 205.7 & 45.8 & 235.6 & 68.5 & 5.0 \\
Heating & 47.7 & 13.4 & 5.8 & 19.4 & 8.6 & 0.5 \\
Hot water & 76.0 & 30.2 & 11.5 & 24.8 & 9.0 & 0.5 \\
Electricity* & 684.2 & 249.2 & 63.1 & 279.8 & 86.1 & 6.0 \\
TOTAL & 3269.8 & 1403.2 & 533.5 & 958.8 & 306.4 & 16.7 \\
\hline Heated floor Area $\left(\mathrm{Mm}^{2}\right)$ &
\end{tabular}

*Electricity includes the electricity for electrical appliances, lighting, hydro pumps, fans and air conditioning; $\mathrm{R}$, residential; SFD, single-family dwelling; T, terraced; MFD, multifamily dwelling; AP, MFD<10floors; HH, MFD>10floors. 
Table 8. Existing heated floor areas and annual final energy demand (in TWh) by end use in the Spanish residential sector (in 2005) and in the non-residential sector (in 2009).

\begin{tabular}{clrrrrrrrr}
\hline \multirow{2}{*}{ End-uses } & \multirow{2}{*}{$R$} & \multicolumn{1}{c}{ R- } & R- & \multirow{2}{*}{ NR } & NR- & NR- & NR- & NR- & T \\
& & SFD & MFD & & C & L & X & \\
\hline Heating & 101.9 & 68.1 & 33.8 & 31.2 & 15.4 & 4.3 & 4.8 & 6.7 & 133.1 \\
Hot water & 25.6 & 9.5 & 16.1 & 1.8 & 0.2 & 0.1 & 1.0 & 0.5 & 27.4 \\
Electricity* & 35.0 & 14.8 & 20.2 & 59.0 & 37.3 & 6.4 & 7.4 & 7.9 & 94.0 \\
TOTAL & 178.4 & 103.1 & 75.2 & 91.9 & 52.9 & 10.8 & 13.2 & 15.1 & 270.3 \\
\hline Heated floor Area $\left(\mathrm{Mm}^{2}\right)$ & 1294.1 & 547.2 & 746.9 & 314.9 & 168.9 & 41.8 & 49.2 & 54.9 & 1609.0 \\
\hline *Electricity includes the electricity for electrical appliances, lighting, hydro pumps, fans and air conditioning; R, \\
residential; NR, non-residential; T, residential and non-residential; SFD, single-family dwelling; MFD, \\
multifamily dwelling; C, commercial; O, office; L, leisure; X, other.
\end{tabular}

Table 9. Existing heated floor areas and annual final energy demand (in TWh) by end use in the UK building sector (in 2010).

\begin{tabular}{|c|c|c|c|c|c|c|c|c|c|c|c|}
\hline End-uses & $R$ & $\begin{array}{c}\text { R- } \\
\text { SFD }\end{array}$ & R-SD & R-T & $\overline{R-B}$ & $\begin{array}{c}\text { R- } \\
\text { MFD }\end{array}$ & $N R$ & NR-O & NR-L & NR-X & $\mathrm{T}$ \\
\hline Heating & 338.8 & 102.1 & 75.4 & 2.7 & 126.0 & 32.7 & 29.3 & 13.6 & 4.1 & 11.6 & 368.1 \\
\hline Hot water & 116.1 & 31.0 & 32.1 & 21.5 & 20.3 & 11.3 & 5.4 & 2.1 & 1.5 & 1.8 & 121.5 \\
\hline Electricity* & 123.1 & 32.9 & 33.9 & 22.7 & 21.7 & 11.9 & 46.7 & 22.7 & 10.7 & 13.3 & 169.8 \\
\hline TOTAL & 571.8 & 164.5 & 140.0 & 45.9 & 166.4 & 55.0 & 81.4 & 38.4 & 16.3 & 26.7 & 653.2 \\
\hline $\begin{array}{l}\text { Heated floor } \\
\text { Area }\left(\mathrm{Mm}^{2}\right)\end{array}$ & 2360.7 & 625.4 & 574.0 & 288.7 & 681.6 & 184.3 & 432. & 135.8 & 114.5 & 181.7 & 2792.8 \\
\hline
\end{tabular}

*Electricity includes the electricity for electrical appliances, lighting, hydro pumps, fans and air conditioning; R, residential; NR, non-residential; T, residential and non-residential; SFD, single-family dwelling; SD, semidetached; T, terraced; B, bungalow; MFD, multifamily dwelling; O, office; L, leisure; X, other.

\section{DISCUSSION}

In describing and modelling energy use in building stocks, the challenge is to find a limited number of building parameters, guarantee their availability and maintain a reduced computational time, while still allowing a fair estimate of buildings' energy use. From the validation of the building stock description of the aggregated data, collected at national or EU levels, the level of detail required by the ECCABS Model is sufficient for the assessment of the energy use of an entire building stock with limited computational effort. Therefore, the modelling procedure with the aggregated description can provide a basis for the investigation of the opportunities and costs for energy savings and $\mathrm{CO}_{2}$ emission reductions. Indeed such investigations have been recently performed by the authors [113][114]. The amount of input parameters allows for an assessment of a comprehensive portfolio of ECMs including changes in different parts of the envelope and building technical systems, as well as the increased supply of on-site renewables. Given the level of aggregation of input data, in particular for the allocation of technologies and fuels for space heating and hot water production and their efficiencies, it should be kept in mind that the results of the assessment are valid for the stock as a whole rather than for a single building. Thus, the purpose of the archetypes is not to provide an ultimate recommendation on how to renovate specific buildings but to identify key technologies and measures for groups of similar buildings, then assess technical, technoeconomic and market potentials for energy saving and $\mathrm{CO}_{2}$ emission reductions within the groups, as well as estimating the effects of energy policies on the groups in a building stock.

In addition, using the archetypes developed in this study provides a detailed description of the energy use of each archetype in terms of net and final energy, end use and fuel. Thus, the combination of archetypal description of the work with the ECCABS Model produces an 
efficient tool with which to generate estimates of data about a building stock that is generally not otherwise available, as the above mentioned data on net and final energy demands per end use and fuels. Such disaggregated building stock data can be used for further analysis of the building sector using other modelling tools.

Further work is required to complete the assessment of the building stock of the entire EU. It is the authors' intention to continue the work by developing corresponding archetypes for Italy and Poland which, together with the four countries investigated in this study, represent about $70 \%$ of the final total energy consumption of buildings within the EU-28. Our hypothesis is that these six countries would allow a good approximation of the EU building stock for the purpose of modelling energy use and evaluating the effect of different ECMs in response to EU policy measures. To analyze the data from these countries, the methodologies used for describing and modelling the building stock may need to be further adapted to account for region-specific characteristics. Furthermore, the possibility of simplifying the number of weather zones within a country should be investigated. While our aggregation results in fifteen zones for the four countries investigated (an increase in the number of zones is expected when including Italy and Poland in the analysis) the above mentioned literature proposes that a smaller number of climate zones should be sufficiently representative of the EU climates. If the division into several climate zones per country proposed in this work is not accounted for, the aggregated description proposed here results in a total of 212 archetypes for the four MSs investigated (33 for France, 50 for Germany, 24 for Spain and 105 for the UK). Work would be necessary to investigate how the grouping of the four countries studied according to the three or five climate zones proposed in [22][23] would affect the methodology used in this paper.

\section{CONCLUSIONS}

The building stocks of four EU countries, which account for over half of the final energy use of buildings within the EU-28, have been described through archetype buildings, including the residential and non-residential sectors. Using the archetypal descriptions as input to the ECCABS bottom-up Building Stock Model yields a final total energy demand which differs by between $-6 \%$ and $2 \%$ from statistics for the four countries investigated, which is considered satisfactory considering the level of aggregation. The building stock description presented through archetype buildings provides a good estimate of the thermal performance of the building stocks; thus, the level of detail appears sufficient to allow an assessment of the effects of applying different ECMs to the building stocks investigated for the current data availability.

In the course of this study, it has become clear that for the EU countries investigated, it is possible to derive datasets regarding the size, physical and technical structure of the existing building stock to define the archetype buildings even though the amount of data available significantly differs between the four countries investigated and data for the NR sector are generally more sparse. Specifically, data available in national statistics are sufficient to quantify for each of the countries studied the number of buildings and their floor areas. Data reported by official authorities responsible for dwellings provide information on building physical characteristics. National building codes can be used to determine the indoor conditions and thermal properties of a building envelope. International statistical data such as from Eurostat, Odysee or GAINS databases are sufficient for the validation of the results obtained at a country level for the overall R and NR sectors, but there is a lack of statistics for validating the modelling results for different subtypes. Nevertheless, these data are neither empirical nor consistent, and ownership and access issues arise. Consequently, there is still a 
need to quantify and analyze the robustness of key data (i.e. indoor temperatures, fuel source for heating and its efficiencies, retrofitting rates, and the frequency of each archetype building in the total stock) and understand their roles in a long-term transformation of a building stock.

\section{ACKNOWLEDGMENTS}

This study has been financed by the AGS Pathways to Sustainable European Energy Systems Project and by the FORMAS Research and Development Grant for projects during 2011 and 2012. A first draft of this paper was presented at the SDEWES Conference, September 22-27, 2013, Dubrovnik, Croatia. Georgina Medina Benejam, Artur Bauer, Sohejl Wanjani, Reza Arababadi and Josep Maria Ribas Portella are gratefully acknowledged for their contributions to the study as part of their MSc theses. We also would like to thank two anonymous reviewers for their insightful comments and suggestions.

\section{REFERENCES}

[1] Kohler N and Hassler U. The building stock as a research object. Building Research \& Information 2002; 30: 226-236.

[2] Swan LG and Ugursal VI. Modeling of end-use energy consumption in the residential sector: A review of modeling techniques. Renewable and Sustainable Energy Reviews 2009; 13: 1819-1835.

[3] Moffatt S. Stock aggregation - Methods for Evaluating the Environmental Performance of Building Stocks, in: Annex 31 Energy related environmental impact of buildings. International Energy Agency (IEA); 2004.

[4] Balaras CA et al. European residential buildings and empirical assessment of the Hellenic building stock, energy consumption, emissions and potential energy savings. Building and Environment 2007; 42: 1298-1314.

[5] Bradley PE and Kohler N. Methodology for the survival analysis of urban building stocks. Building Research \& Information 2007; 35: 529- 542.

[6] Pérez-Lombard L, Ortiz J and Pout C. A review on buildings energy consumption information. Energy and Buildings 2008; 40: 394-398.

[7] Dineen D and Ó Gallachóir BP. Modelling the impacts of building regulations and a property bubble on residential space and water heating. Energy and Buildings 2011; 43: 166-178.

[8] Summerfield AJ and Lowe R. Challenges and future directions for energy and buildings research. Building Research \& Information 2012; 40: 391-400.

[9] Marchal J. Modélisation des Performances énergétiques du parc de logements - État énergétique du parc en 2008. L'Agence nationale de l'habitat (ANAH); 2008.

[10] Martinlagardette C. Characterisation of the French dwelling stock for application to bottom-up energy modelling. MSc Thesis, Chalmers University of Technology, Gothenburg, Sweden; 2009.

[11] Walberg D et al. Wohnungsbau in Deutschland - Modernisierung oder Bestandsersatz. ARGE Arbeitsgemeinschaft für zeitgemäßes Bauen e.V.; 2011.

[12] McKenna R et al. Energy efficiency in the German residential sector: A bottom-up buildingstock-model-based analysis in the context of energy-political targets. Building and Environment 2013; 62: 77-88.

[13] Institut Cerdà. La contribució de l'habitatge de Catalunya a la reducció d'emissions de gasos amb efecte d'hivernacle. Generalitat de Catalunya, Departament de Medi Ambient i Habitatge; 2006.

[14] Estrategia de ahorro y eficiencia energética en España 2004-2012 Sector Edificación. Ministerio de Economía, Secretaría de Estado de energía y desarrollo industrial de la pequeña y mediana empresa; 2003. 
[15] Collins L, Natarajan S and Levermore G. Climate change and future energy consumption in UK housing stock. Building Services Engineering Research and Technology 2010; 31: 75-90.

[16] Firth SK, Lomas KJ and Wright AJ. Targeting household energy-efficiency measures using sensitivity analysis. Building Research \& Information 2010; 38: 25-41.

[17] Johnston D. A Physically-based energy and carbon dioxide emission model of the UK housing stock. PhD Thesis, Leeds Metropolitan University, UK; 2003.

[18] Choudhary R. Energy analysis of the non-domestic building stock of Greater London, Building and Environment 2012; 51: 243-254.

[19] Kavgic $M$ et al. A review of bottom-up building stock models for energy consumption in the residential sector. Building and Environment 2010; 45:1683-1697.

[20] Petersdorff C. et al. Mitigation of $\mathrm{CO}_{2}$ Emissions from the EU-15 Building Stock. Beyond the EU Directive on the Energy Performance of Buildings. Ecofys, Cologne, Germany; 2004.

[21] Dascalaki E et al. Typology Approach for Building Stock Energy Assessment - Final project report. Loga T et al. (Ed), Institut Wohnen und Umwelt GmbH (IWU), Darmstadt, Germany; 2012.

[22] Ciscar JC et al. Climate change impacts in Europe. Final report of the PESETA research project. JRC, Seville, Spain; 2009.

[23] Tsikaloudaki K, Laskos K and Bikas D. On the Establishment of Climatic Zones in Europe with Regard to the Energy Performance of Buildings. Energies 2012; 5: 32-44.

[24] Eurostat Database. European Commission, Luxembourg; 2014. [Online database]

[25] Wilhelmsen AM. Methods for surveying and describing the building stock, Proceedings of the CIB W70 1981 Symposium. Swedish Council for Building Research; 1982.

[26] Shorrock LD, Henderson J and Utley JI. Reducing carbon emissions from the UK housing stock. Housing Centre, BRE Environment. BRE Press, Garston, Watford; 2005.

[27] Modelling Greenhouse Gas Emissions from Scottish Housing: Final Report. Cambridge Architectural Research, Cambridge Econometrics, Roger Talbot \& Associates Ltd, Alembic Research; 2009.

[28] Hilderson W, Mlecnik E and Cré J. Potential of Low Energy Housing Retrofit, Final Report Low Energy Housing Retrofit (LEHR), Belgian Science Policy (Programme to stimulate knowledge transfer in areas of strategic importance - TAP2), Brussels, Belgium; 2010.

[29] Energi i bebyggelsen - tekniska egenskaper och beräkningar. Boverket, Karlskrona, Sweden; 2010.

[30] Majcen D, Itard LCM and Visscher H. Theoretical vs. actual energy consumption of labelled dwellings in the Netherlands: Discrepancies and policy implications. Energy Policy 2013; 54: 125136.

[31] Buratti D, Barbanera M and Palladino D. An original tool for checking energy performance and certification of buildings by means of Artificial Neural Networks. Applied Energy 2014; 120: 125132

[32] Dascalaki EG et al. Data collection and analysis of the building stock and its energy performance-An example for Hellenic buildings. Energy and Buildings 2010; 42: 1231-1237.

[33] Mastrucci A et al. Estimating energy savings for the residential building stock of an entire city: A GIS-based statistical downscaling approach applied to Rotterdam. Energy and Buildings 2014; 75: 358-367.

[34] ODYSSEE Database. Enerdata; 2014. [Online database]

[35] Database GAINS. International Institute for Applied Systems Analysis (IIASA), Laxenburg; Austria; 2010. 
[36] MURE II Policy Database (Mesures d'Utilisation Rationnelle de l'Energie). Innovation for sustainability ISIS; 2013. [Online database]

[37] Poel B. EPA-NR Energy Performance Assessment for Existing Non Residential Buildings Overview of results. BuildDesk, Arnhem, The Netherlands; 2007.

[38] Gruber E et al. EL-TERTIARY Monitoring Electricity Consumption in the Tertiary Sector, Intelligent Energy - Europe (IEE); 2008.

[39] Ó Broin E. Energy Demands of European Buildings: A Mapping of Available Data, Indicators and Models. MSc Thesis, Chalmers University of Technology, Gothenburg, Sweden; 2007.

[40] Data Hub for energy performance of buildings, Buildings Performance Institute Europe (BPIE); 2014. [Online database]

[41] Mata É, Sasic Kalagasidis A and Johnsson F. A modelling strategy for energy, carbon, and cost assessments of building stocks. Energy and Buildings 2013; 56: 404-414.

[42] Ribas Portella JM. Bottom-up description of the French building stock, including archetype buildings and energy demand. MSc Thesis, Chalmers University of Technology, Gothenburg, Sweden; 2012.

[43] Medina Benejam G. Bottom-up characterization of the Spanish building stock - Archetype buildings and energy demand. MSc Thesis, Chalmers University of Technology, Gothenburg, Sweden; 2011.

[44] Wanjani S and Bauer A. Bottom-up characterization of the residential German building stock Reference buildings and energy demand. MSc Thesis, Chalmers University of Technology, Gothenburg, Sweden; 2012.

[45] Arababadi R. Energy use in the EU building stock - Case study: UK. MSc Thesis, Linköping University, Linköping, Sweden; 2012.

[46] Meteotest, Meteonorm Version 6, Global Meteorological Database for Engineers, Planners and Education. Bern, Switzerland 2009.

[48] Dascalaki EG et al. Building typologies as a tool for assessing the energy performance of residential buildings - A case study for the Hellenic building stock.Energy and Buildings 2011; 43: 3400-3409.

[49] Clarke JA et al. Energy, carbon and cost performance of building stocks: upgrade analysis, energy labelling and national policy development. Advances in Building Energy Research 2009; 3: 1-20.

[50] La consommation d'énergie du secteur tertiaire. Ministère de l'Écologie, du Développement Durable et de l'Énergie; 2007. [Online statistics]

[51] Décret n²006-592 du 24 mai 2006 relatif aux caractéristiques thermiques et à la performance énergétique des constructions.

[52] Arrêté du 29 novembre 2000 relatif aux caractéristiques thermiques des bâtiments nouveaux et des parties nouvelles de bâtiments.

[53] Décret $\mathrm{n}^{\circ}$ 76-246 du 12 mars 1976 fixant les règles de construction en ce qui concerne l'isolation thermique ainsi que les normes d'équipement et de fonctionnement des installations de conditionnement d'air dans les bâtiments autres que les bâtiments d'habitation.

[54] Deutsche Gebäudetypologie - Systematik und Datensätze. IWU; 2005.

[55] Real decreto 314/2006 por el que se aprueba el Código Técnico de la Edificación (CTE).

[56] Palmer J and Cooper I. Great Britain's Housing Energy Fact File, Department of Energy and Climate Change (DECC); 2011.

[57] Pout CH, Moss SA and Davidson PJ. Non-Domestic Building Energy Fact File, BRE Report BR339, 1998. 
[58] Approved Document L: Conservation of Fuel and Power. HM Government; 1995.

[59] Approved Document L: Conservation of Fuel and Power. HM Government; 2002.

[60] Approved Document L: Conservation of Fuel and Power. HM Government; 2006.

[61] Approved Document L: Conservation of Fuel and Power. HM Government; 2012.

[62] MetOffice, UK mapped climate averages 2000; http://www.metoffice.gov.uk

[63] Méthode 3CL-DPE. Annex 1 in: Arrêté portant approbation de diverses méthodes de calcul pour le diagnostic de performance énergétique en France métropolitaine NOR : SOCU 0610563 A. République Française, Ministère de l'emploi, de la cohésion sociale et du logement.

[64] Les chiffres clés du bâtiment. Agence de l'Environnement et de la Maîtrise de l'Energie (ADEME); 2011.

[65] Pompes à chaleur et habitat, Les cahiers du Clip n ${ }^{\circ} 18$ - Janvier 2007. Institut du Développement Durable et des Relations Internationales (IDDRI); 2007.

[66] Arrêté du 22 décembre 2003 portant modification de l'arrêté du 29 novembre 2000, complété par l'arrêté du 9 novembre 2001 relatif aux caractéristiques thermiques des bâtiments nouveaux et des parties nouvelles de bâtiments.

[67] Arrêté du 24 mars 1982 relatif à l'aération des logements.

[68] Boermans T and Petersdorff C. U-values For Better Energy Performance of Buildings. ECOFYS, Cologne, Germany; 2007.

[69] Code du travail Article R4222-6 Créé par Décret n²008-244 du 7 mars 2008 - art. (V).

[70] Calcul provisionnel des consommations d'énergie - Bâtiments non résidentiels, Collection des guides de l'AICVF; 2000.

[71] Annexe a l'arrêté du 8 août 2008 portant approbation de la méthode de calcul Th-C-E ex prévue par l'arrêté du 13 juin 2008 relatif à la performance énergétique des bâtiments existants de surface supérieure à 1000 mètres carrés, lorsqu'ils font l'objet de travaux de rénovation importants.

[72] Filfli S. Optimisation bâtiment/système pour minimiser les consommations dues à la climatisation. PhD Thesis, École des Mines de Paris, France; 2006.

[73] Pla de Millora Energètica de Barcelona. Ajuntament de Barcelona; 2002.

[74] Raux CX et al. Bilans énergétiques Transport-Habitat et méthodologie BETEL. ETHEL. Rapport R2. Action Concertée CNRS - Ministère de la Recherche. LET, Lyon, France; 2005.

[75] Négawatt. 2011. Scénario Négawatt 2011. Paris. [Online presentation]

[76] Les consommations d'énergie dans les bureaux en Île-de-France en 2009. ARENE; 2009.

[77] Routhier JL et al. Energie Transports Habitat Environnement Localisations ETHEL II Rapport final. Convention Agence de l'Environnement et de la Maîtrise de l'Energie (ADEME); 2009.

[78] Consommation d'énergie des bâtiments franciliens d'enseignement. ARENE; 2011.

[79] Bilan énergétique de la France pour 2010. Commissariat général au développement durable; 2011.

[79] Sistema de información sobre eficiencia energética de calderas. Instituto para la Diversificación y el Ahorro de la Energía (IDAE) [Online tool]

[80] Diefenbach N et al. Datenbasis Gebäudebestand - Datenerhebung zur energetischen Qualität und zu den Modernisierungstrends im deutschen Wohngebäudebestand. Institut Wohnen und Umwelt GmbH (IWU), Darmstadt, Germany; 2010.

[81] Loga T and Imkeller-Benjes U. Energiepaß Heizung/Warmwasser - Energetische Qualität von Baukörper und Heizungssystem. IWU, Darmstadt, Germany, 1997. 
[82] Nipkow J, Gasser S and Bush E. Der typische Haushalt-Stromverbrauch. AE Bulletin SEV/AES 19/2007: 24-26.

[83] Loga T et al. Entwicklung eines vereinfachten statistisch abgesicherten Verfahrens zur Erhebung von Gebäudedaten für die Erstellung des Energieprofils von Gebäuden . IWU, Darmstadt, Germany; 2005.

[84] Real Decreto 1490/1975 de 12 de junio, por el que se establecen medidas a adoptar en las edificaciones con objeto de reducir el consumo de energía.

[85] Real Decreto 2429/1979 de 6 de julio, por el que se aprueba la norma básica de la edificación NBE-CT-79, sobre condiciones térmicas en los edificios.

[86] Real Decreto 1027/2007 de 20 de julio, por el que se aprueba el Reglamento de Instalaciones Térmicas en los Edificios (RITE).

[87] Condiciones de aceptación de Programas Informáticos Alternativos a LIDER y CALENER. Ministerio de Industria, Turismo y Comercio, Madrid, Spain 2009.

[88] Informe anual de consumos energéticos - Año 2009. Instituto para la Diversificación y el Ahorro de la Energía (IDAE); 2010.

[89] Instituto Nacional de Estadística (INE); 2007. [Online database]

[90] Approved document Part F: Ventilation. HM Government; 2010.

[91] Environmnetal design, CIBSE Guide A. CIBSE Publications; 2006.

[92] Energy consumption in the United Kingdom: 2011. Department of Energy and Climate Change (DECC).

[93] Boiler Efficiency Database. BRE. [Online database]

[94] Clinch JP, Healy JD and King C. Modelling improvements in domestic energy efficiency. Environmental Modelling \& Software 2001; 16: 87-106.

[95] Jacquot A and Minodier C. Enquêtes annuelles de recensement 2004 et 2005. INSEE Premiere $\mathrm{N}^{\circ}$ 1060; 2006.

[96] Levron C. La loi SRU : une loi en péril ? Controverses et difficultés d'application. Mémoire, Université Paris X - Nanterre, France; 2007.

[97] Les organismes de logement social. Chiffres clés 2007-2008. Ministère de l'Écologie, du Développement durable et de l'Énergie; 2010.

[98] Van de Maele P. Grenelle de l'environnement - Chantier $n^{\circ} 2$ Logements sociaux et rénovation urbaine. Ministère de l'Écologie, du Développement durable et de l'Énergie; 2008.

[99] Base de données Sit@del2, Ministère de l'Écologie, du Développement durable et de l'Énergie. [Online database]

[100] Girault, M. Le parc immobilier du secteur tertiaire. Enerdata; 2001.

[101] Enquête sur les points de vente du commerce de détail en 2004. Institut national de la statistique et des études économiques (INSEE).

[102] Diefenbach N and Loga T. Basisdaten für Hochrechnungen mit der Deutschen Gebäudetypologie des IWU. IWU, Darmstadt, Germany; 2007.

[103] Visados de dirección de obra nueva. Boletín estadístico online 2011. Ministerio de Fomento. [Online statistics]

[104] Anuario estadístico 2009, Ministerio de Fomento; 2009. [Online statistics]

[105] www.mathworks.com 
[106] Les chiffres clés du bâtiment. Agence de l'Environnement et de la Maîtrise de l'Energie (ADEME); 2006.

[107] La consommation d'énergie du secteur tertiaire. Ministère de l'Écologie, du Développement durable et de l'Énergie; 2007.

[108] Statistisches Bundesamt. Wiesbaden, Germany; 2010. [Online statistics]

[109] Energie in Deutschland - Trends und Hintergründe zur Energieversorgung. Bundesministerium für Wirtschaft und Technologie Öffentlichkeitsarbeit, Berlin, Germany; 2010.

[110] Booth AT, Choudhary R, Spiegelhalter DJ. Handling uncertainty in housing stock models. Building and Environment 2012; 48: 35-47.

[111] Campagne nationale Logements Etat de la qualité de l'air dans les logements français. Rapport final. Observatoire de la Qualité de l'Air Intérieure; 2006.

[112] Huebner GM et al. Heating patterns in English homes: Comparing results from a national survey against common model assumptions. Building and Environment 2013; 70: 298-305

[113] Mata É, Sasic Kalagasidis A and Johnsson F. Energy usage and technical potential for energy saving measures in the Swedish residential buildings, Energy Policy 2013; 55: 404-414.

[114] Mata É, Sasic Kalagasidis A and Johnsson F. Opportunities and costs associated with energy conservation in the Spanish building stock. Submitted for publication to Energy and Buildings.

[115] Nik VM, Sasic Kalagasidis A. Impact study of the climate change on the energy performance of the building stock in Stockholm considering four climate uncertainties. Building and Environnent 2013; 60: 291-304. 